\title{
Contribution of mineral nutrients from source to sink organs in rice under different nitrogen fertilization
}

\author{
Zunxin Wang ${ }^{1}$. Fangfang Zhang ${ }^{1} \cdot$ Feng Xiao $^{1} \cdot$ Yang Tao $^{1} \cdot$ Zhenghui Liu $^{1,2} \cdot$ Ganghua $\mathrm{Li}^{1} \cdot$ Shaohua Wang ${ }^{1}$. \\ Yanfeng Ding ${ }^{1,2}$
}

Received: 23 December 2017 / Accepted: 13 June 2018 / Published online: 15 June 2018

(c) The Author(s) 2018

\begin{abstract}
The pot experiment with three treatments of nitrogen $(\mathrm{N})$ topdressing was performed with the japonica rice cultivar viz. Huaidao 5. Remobilization of nine mineral nutrients including N, phosphorus $(\mathrm{P})$, potassium $(\mathrm{K})$, calcium $(\mathrm{Ca})$, magnesium $(\mathrm{Mg})$, iron $(\mathrm{Fe})$, zinc $(\mathrm{Zn})$, manganese $(\mathrm{Mn})$, and copper $(\mathrm{Cu})$ was measured from the source organs including bracts, leaf, and sheath to sink rice grain. Experimental results showed considerable contribution of bracts to grain for $\mathrm{N}, \mathrm{Mg}$, and $\mathrm{Zn}$, with the averages contributions of 5.96, 12.56, and $12.34 \%$, respectively, indicating a positive role of rice bracts in $\mathrm{N}, \mathrm{Mg}$, and $\mathrm{Zn}$ remobilization during grain filling. By contrast, minor contribution of bracts to grain $\mathrm{P}, \mathrm{K}$, and $\mathrm{Cu}$ was revealed, with the contribution rate being 0.99, 3.90, and 3.05\%, respectively. Further, a net increase in Ca and Fe concentrations of bracts was detected, implying that bracts function as a sink of these mineral nutrients. In addition, grains produced at a moderate level of $\mathrm{N}$ topdressing had higher $\mathrm{Fe}$ and similar $\mathrm{Zn}$ concentration in comparison with those at high $\mathrm{N}$ level, suggesting the possibility of $\mathrm{N}$ management for maintaining $\mathrm{Fe}$ and $\mathrm{Zn}$ level under high yielding conditions.
\end{abstract}

Keywords Rice bracts $\cdot$ Mineral nutrients $\cdot$ Remobilization $\cdot$ Nitrogen fertilization $\cdot$ Source/sink relation $\cdot$ Iron $\cdot$ Zinc

\section{Introduction}

Mineral elements occupy an essential role in human nutrition (Huang et al. 2016). Deficiencies of micronutrients like zinc $(\mathrm{Zn})$ and iron $(\mathrm{Fe})$, recognized as hidden hunger, are the most prevalent health disorders worldwide, affecting nearly two billion people (Promchan et al. 2016). Rice is a major staple crop, supplying the bulk of calories and the majority of daily dietary nutrients for billions of people (Cakmak 2008; Waters et al. 2009). Therefore, enrichment of the staple crops like rice with essential nutrients, especially $\mathrm{Zn}$ and $\mathrm{Fe}$, is currently a high-priority research area in crop science.

Biofortification of breeding crops with condensed micronutrients like $\mathrm{Fe}, \mathrm{Zn}$, and $\beta$-carotene through conventional breeding and modern biotechnology, is considered to be the most sustainable and cost-effective strategy for overcoming

Zhenghui Liu

liuzh@njau.edu.cn

1 College of Agronomy, Nanjing Agricultural University, Nanjing 210095, People's Republic of China

2 Jiangsu Collaborative Innovation Center for Modern Crop Production, Nanjing 210095, People's Republic of China hidden hunger (Murgia et al. 2012). In addition, agronomic biofortification is viewed as complementary to breeding strategies for optimizing and ensuring the success of genetic biofortification in the long term (Cakmak 2008). Recent studies have shown that improving nitrogen $(\mathrm{N})$ status of crops may play a pivotal role in uptake of mineral nutrients, and distribution and accumulation of mineral nutrients in edible parts of crops (Erenoglu et al. 2011). Soil and foliar application of $\mathrm{N}$ enhanced grain $\mathrm{Zn}$ concentration in wheat (Kutman et al. 2011). In rice, $\mathrm{N}$ application affected grain composition, and a moderate level of $\mathrm{N}$ application was favorable for promoting accumulation of micronutrients like copper $(\mathrm{Cu}), \mathrm{Fe}$, manganese $(\mathrm{Mn})$, and $\mathrm{Zn}$ in brown rice (Hao et al. 2007). A previous study showed that $\mathrm{N}$ promotes $\mathrm{Fe}$ accumulation but depresses $\mathrm{Zn}$ accumulation in milled rice (Lin et al. 2014). However, the physiological mechanisms of how $\mathrm{N}$ affects remobilization of $\mathrm{Fe}$ and $\mathrm{Zn}$ in plants are largely unknown.

Flag and upper leaves are the main source organs of assimilates and mineral nutrients for grain filling (Sperotto et al. 2009; Zhang et al. 2017). In addition, non-leaf organs such as stems, branches, sheaths, glumes/bracts, and awns also have chloroplasts and photosynthetic activities, 
therefore these are also considered source organs. In wheat, leaves contributed $40 \%$, glumes $23 \%$, stem $23 \%$, and roots $16 \%$ of the $\mathrm{N}$ remobilized to and accumulated in grains (Simpson et al. 1983). Pearson and Rengel (1994) suggested that wheat glumes are transient storage organs of $\mathrm{Zn}$ and Mn translocated from leaves and subsequently loaded into the developing grain. A study on rice revealed a substantial contribution rate of protein- $\mathrm{N}$ from bracts to grains, being as high as nearly $10 \%$ (Zhang et al. 2017). However, the remobilization of other nutrients like phosphorus $(\mathrm{P})$, potassium $(\mathrm{K})$, magnesium $(\mathrm{Mg}), \mathrm{Fe}$, and $\mathrm{Zn}$ from bracts and its contribution to grain mineral nutrient accumulation is largely unknown and requires a further investigation.

The current experimentation was conducted a pot experiment with three levels of $\mathrm{N}$ topdressing, and estimate the apparent contribution rate of $\mathrm{N}, \mathrm{P}, \mathrm{K}, \mathrm{Ca}, \mathrm{Mg}, \mathrm{Fe}, \mathrm{Zn}, \mathrm{Mn}$, and $\mathrm{Cu}$ from vegetative organs including bracts, leaf, and sheath to grains. The objective of the current study was to elucidate the role of rice bracts in accumulation of grain mineral nutrients. In addition, the study of $\mathrm{N}$ effect on remobilization of mineral nutrients from source to sink organs and their accumulation in grains was investigated, with the aim of developing an agronomic strategy for fortifying rice grains with $\mathrm{Fe}$ and $\mathrm{Zn}$.

\section{Materials and methods}

\section{Plant material and experiment design}

The pot experiment was conducted in a field environment at the Danyang experimental station, Jiangsu Province, China $\left(31^{\circ} 54^{\prime} 31^{\prime \prime} \mathrm{N}, 119^{\circ} 28^{\prime} 21^{\prime \prime} \mathrm{E}\right)$ in the summer of 2016 , using a japonica rice cultivar viz. Huaidao 5 . The pots were $30 \mathrm{~cm}$ in height and $34 \mathrm{~cm}$ in diameter, and were filled with $15 \mathrm{~kg}$ fine-grained soil. Seeds were sown in the nursery beds on May 30, and 4-week-old seedlings were transplanted to pots on June 28, with each pot having six seedlings.

The soil type was clay soil, containing $25.7 \mathrm{~g} \mathrm{~kg}^{-1}$ organic matter, $1.1 \mathrm{~g} \mathrm{~kg}^{-1}$ total $\mathrm{N}$, and $23.8 \mathrm{mg} \mathrm{kg}^{-1}$ available $\mathrm{P}$. The total concentrations of soil $\mathrm{P}, \mathrm{K}, \mathrm{Ca}, \mathrm{Mg}, \mathrm{Fe}, \mathrm{Zn}$, $\mathrm{Mn}$, and $\mathrm{Cu}$ were 519.8, 26298.1, 1140.1, 3077.5, 14621.5, $50.2,286.8$, and $14.1 \mathrm{mg} \mathrm{kg}^{-1}$, respectively. The EDTA extractable $\mathrm{K}, \mathrm{Ca}$, and $\mathrm{Mg}$ concentrations were 89.7, 89.6, and $601.6 \mathrm{mg} \mathrm{kg}^{-1}$, respectively, and the DTPA extractable $\mathrm{Fe}, \mathrm{Zn}, \mathrm{Mn}$, and $\mathrm{Cu}$ were 40.1, 1.7, 266.9, and $2.5 \mathrm{mg} \mathrm{kg}^{-1}$, respectively. The EDTA extractable $\mathrm{K}$ and $\mathrm{Zn}$ were in the medium level for the clay soil, while others were among the high levels, as classified by Bao (2000).

Before transplanting, basal fertilizers were applied as $1.0 \mathrm{~g} \mathrm{~N}, 1.2 \mathrm{~g} \mathrm{P}_{2} \mathrm{O}_{5}$, and $0.9 \mathrm{~g} \mathrm{~K}_{2} \mathrm{O}$ per pot. $\mathrm{N}$ topdressing was split equivalently at two stages, the panicle initiation stage (4th leaf age in reverse order) and the middle stage (2nd leaf age in reverse order). Three levels of $\mathrm{N}$ topdressing were applied as follows: (1) LN, low N level ( $0.8 \mathrm{~g} \mathrm{~N} /$ pot); (2) $\mathrm{MN}$, medium $\mathrm{N}$ level (1.6 g N/pot); and (3) HN, high $\mathrm{N}$ level ( $2.4 \mathrm{~g} \mathrm{~N} /$ pot). Each $\mathrm{N}$ treatment had 50 pots, and water management was implemented according to approaches for high yielding (Chen et al. 2016).

\section{Sampling and chemical analysis}

Samples of the top three leaves and their sheaths, and grains and their bracts were collected at the beginning of grain filling, the 7th day after anthesis (7 DAA), and at maturity (35 DAA). The bracts included lower glume, upper glume, lemma, and palea, as described by Zhang et al. (2017). Enzymes were deactivated by heating at $105{ }^{\circ} \mathrm{C}$ for $1 \mathrm{~h}$ in an oven. Then the samples were dried to a constant weight at $75{ }^{\circ} \mathrm{C}$ for $48 \mathrm{~h}$. After that, dry matter was weighed and samples were milled into powder and stored in plastic bags at room temperature for mineral analysis.

Nitrogen concentration was determined using the semimicro-Kjeldahl method. Inductively coupled plasma optical emission spectrometry (ICP-OES 710; Agilent Technologies, USA) was used to determine the contents of $\mathrm{P}, \mathrm{K}$, $\mathrm{Ca}, \mathrm{Mg}, \mathrm{Fe}, \mathrm{Zn}, \mathrm{Mn}$, and $\mathrm{Cu}$. Samples $(\sim 0.50 \mathrm{~g})$ were wet digested with $10 \mathrm{~mL} \mathrm{HNO}_{3}-\mathrm{HClO}_{4}$ mixed acid (3:1). Argon was used as the make-up gas, and parameters of ICP-OES were as follows: radio frequency power, $1.1 \mathrm{KW}$; plasma gas flow, 15.0 $\mathrm{L} \mathrm{min}^{-1}$; auxiliary gas flow, $1.50 \mathrm{~L} \mathrm{~min}^{-1}$; nebulizer pressure, $200 \mathrm{~N}$; delay time, $15 \mathrm{~s}$; flush time, $10 \mathrm{~s}$; and read time, $5 \mathrm{~s}$. Standard solutions of the eight mineral elements (1000 ppm, Merck, Germany) were used to obtain the calibration curve, with correlation coefficients more than 0.999 in this study. Each sample was measured in triplicate.

\section{Statistical analysis}

Samples were analyzed in triplicate and mean values were used for comparison. The analysis of variance was performed using Least Significant Difference (LSD) test in SPSS 17.0 (Statistical Product and Service Solutions, IBM).

\section{Results \\ Dry matter accumulation of leaf, sheath, bracts, and grain}

Dry matter weight decreased slightly in leaves and their sheaths with the progress of grain filling (Table 1). Similarly, dry matter in bracts was slightly lower at 35 DAA than at 7 DAA (Table 1), indicating the translocation of assimilates in these organs. Nitrogen significantly promoted dry 
Table 1 Dry matter accumulation of leaf, sheath, and bracts and grain yield under three $\mathrm{N}$ treatments

\begin{tabular}{|c|c|c|c|c|c|c|}
\hline \multicolumn{4}{|c|}{ Dry matter (g/plant) } & \multicolumn{3}{|c|}{ Grain yield and yield components } \\
\hline Organ & $\begin{array}{l}\text { Nitrogen } \\
\text { treatment }\end{array}$ & $7 \mathrm{DAA}$ & 35 DAA & & $\begin{array}{l}\text { Nitrogen } \\
\text { treatmen }\end{array}$ & \\
\hline \multirow[t]{4}{*}{ Leaf } & $\mathrm{LN}$ & $0.424 c^{*}$ & $0.298 \mathrm{c}$ & Panicles per plant & $\mathrm{LN}$ & $4.83 b$ \\
\hline & $\mathrm{MN}$ & $0.453 \mathrm{a}$ & $0.380 \mathrm{~b}$ & & $\mathrm{MN}$ & $5.39 \mathrm{a}$ \\
\hline & $\mathrm{HN}$ & $0.446 b$ & $0.395 \mathrm{a}$ & & $\mathrm{HN}$ & $5.50 \mathrm{a}$ \\
\hline & Mean & 0.441 & 0.358 & & Mean & 5.24 \\
\hline \multirow[t]{4}{*}{ Sheath } & $\mathrm{LN}$ & $0.689 \mathrm{a}$ & $0.486 \mathrm{~b}$ & Grains per panicle & $\mathrm{LN}$ & $102.27 \mathrm{c}$ \\
\hline & $\mathrm{MN}$ & $0.650 \mathrm{~b}$ & $0.522 \mathrm{a}$ & & $\mathrm{MN}$ & $108.93 b$ \\
\hline & $\mathrm{HN}$ & $0.651 b$ & $0.478 \mathrm{~b}$ & & $\mathrm{HN}$ & $120.40 \mathrm{a}$ \\
\hline & Mean & 0.663 & 0.495 & & Mean & 110.53 \\
\hline \multirow[t]{4}{*}{ Bracts } & $\mathrm{LN}$ & $0.387 b$ & $0.377 \mathrm{~b}$ & Setting rate $(\%)$ & $\mathrm{LN}$ & $95.44 \mathrm{a}$ \\
\hline & $\mathrm{MN}$ & $0.428 \mathrm{a}$ & $0.381 \mathrm{ab}$ & & MN & $95.89 \mathrm{a}$ \\
\hline & $\mathrm{HN}$ & $0.420 \mathrm{a}$ & $0.391 \mathrm{a}$ & & $\mathrm{HN}$ & $94.85 \mathrm{a}$ \\
\hline & Mean & 0.412 & 0.383 & & Mean & 95.39 \\
\hline \multirow[t]{8}{*}{ Grain } & $\mathrm{LN}$ & $0.077 \mathrm{c}$ & $2.306 \mathrm{c}$ & Grain weight (g) & LN & $26.06 \mathrm{~b}$ \\
\hline & $\mathrm{MN}$ & $0.110 \mathrm{~b}$ & $2.570 \mathrm{~b}$ & & $\mathrm{MN}$ & $27.13 \mathrm{a}$ \\
\hline & $\mathrm{HN}$ & $0.129 \mathrm{a}$ & $2.735 \mathrm{a}$ & & $\mathrm{HN}$ & $26.20 \mathrm{~b}$ \\
\hline & Mean & 0.105 & 2.537 & & Mean & 14.68 \\
\hline & & & & Yield (g/plant) & $\mathrm{LN}$ & $12.30 \mathrm{~b}$ \\
\hline & & & & & $\mathrm{MN}$ & $15.27 \mathrm{a}$ \\
\hline & & & & & $\mathrm{HN}$ & $16.46 \mathrm{a}$ \\
\hline & & & & & Mean & 14.68 \\
\hline
\end{tabular}

Low rate of $\mathrm{N}$ topdressing (LN, $0.8 \mathrm{~g} \mathrm{~N} /$ pot); medium rate of $\mathrm{N}$ (MN, $1.6 \mathrm{~g} \mathrm{~N} /$ pot); high rate of $\mathrm{N}$ (HN, $2.4 \mathrm{~g} \mathrm{~N} /$ pot)

$D A A$ day after anthesis

*Data within a column followed by different lowercase letters are significantly different at $P<0.05$ matter accumulation in leaves, with HN exhibiting the largest influence.

As expected, $\mathrm{N}$ topdressing significantly increased grain yield per plant, leading to more panicles per plant and more grains per panicle (Table 1). Although MN resulted in heavier grains, there was no significant difference between the high and low $\mathrm{N}$ treatments. Grain yields of MN (15.27 g/ plant) and $\mathrm{HN}$ (16.46 g/plant) were significantly higher than that of LN (12.30 g/plant). Although the value of HN was higher than that of $\mathrm{MN}$, there was no statistically significant difference between them.

\section{Concentrations of mineral nutrients in leaf, sheath, bracts, and grain}

Concentrations of $\mathrm{N}, \mathrm{P}, \mathrm{K}, \mathrm{Mg}, \mathrm{Zn}$, and $\mathrm{Cu}$ in leaf, sheath, and bracts decreased as grain filling progressed, and concentrations were higher at 7 DAA than at maturity of 35 DAA (Tables 2, 3). In contrast, concentrations of $\mathrm{Ca}$ and Fe were lower at 35 DAA than at 7 DAA. The concentration of Mn increased in leaf but decreased in sheath and bracts from 7 DAA to 35 DAA.
In general, $\mathrm{N}$ topdressing had a positive influence on concentrations of mineral nutrients in leaf, sheath, and bracts both at 7 DAA and at 35 DAA. Concentrations of the nine mineral nutrients in grains decreased as grain filling progressed, being higher at early stage than at late stage (Tables 2, 3). This is attributed to the dilution effect of grain dry matter accumulation, which had a higher rate than those of the nine mineral nutrients. Of interest was that the concentrations of $\mathrm{Ca}, \mathrm{Mg}, \mathrm{Fe}$, and $\mathrm{Mn}$ dropped drastically from 7 DAA to 35 DAA, indicating that these mineral nutrients were translocated to grains mainly at early stage of grain filling. In addition, high $\mathrm{N}$ topdressing significantly lowered Fe concentration in mature grains (35 DAA) as compared with LN; however, concentrations of $\mathrm{Fe}$ and $\mathrm{Zn}$ were not significantly altered by MN (Table 3).

Noticeably, the grain P concentrations of HN treatments were significantly higher than that of LN at 7 DAA (Table 2). Although the $\mathrm{P}$ concentrations of grains between $\mathrm{HN}$ and $\mathrm{LN}$ were not significantly different, there was a relatively lower effect of HN compared to LN at 35 DAA. In addition, the grain $\mathrm{P}$ concentrations of HN treatments were statistically lower than that of MN (Table 2), which was consistent with our previous study (Bi et al. 2013). 
Table 2 Concentrations of macronutrients in leaf, sheath, bracts, and grain under three $\mathrm{N}$ treatments

\begin{tabular}{|c|c|c|c|c|c|c|c|c|c|c|c|}
\hline \multirow[t]{2}{*}{ Organ } & \multirow{2}{*}{$\begin{array}{l}\text { Nitrogen } \\
\text { treatment }\end{array}$} & \multicolumn{2}{|c|}{$\mathrm{N}\left(\mathrm{mg} \mathrm{g}^{-1}\right)$} & \multicolumn{2}{|c|}{$\mathrm{P}\left(\mathrm{mg} \mathrm{g}^{-1}\right)$} & \multicolumn{2}{|c|}{$\mathrm{K}\left(\mathrm{mg} \mathrm{g}^{-1}\right)$} & \multicolumn{2}{|c|}{$\mathrm{Ca}\left(\mathrm{mg} \mathrm{g}^{-1}\right)$} & \multicolumn{2}{|c|}{$\mathrm{Mg}\left(\mathrm{mg} \mathrm{g}^{-1}\right)$} \\
\hline & & 7 DAA & $35 \mathrm{DAA}$ & 7 DAA & $35 \mathrm{DAA}$ & 7 DAA & 35 DAA & 7 DAA & $35 \mathrm{DAA}$ & 7 DAA & 35 DAA \\
\hline \multirow[t]{4}{*}{ Leaf } & $\mathrm{LN}$ & $26.71 c^{*}$ & $10.67 \mathrm{c}$ & $2.38 \mathrm{a}$ & $1.88 \mathrm{a}$ & $15.96 \mathrm{~b}$ & $14.60 \mathrm{~b}$ & $4.83 b$ & $7.71 \mathrm{~b}$ & $2.66 \mathrm{~b}$ & $2.20 \mathrm{c}$ \\
\hline & $\mathrm{MN}$ & $29.72 b$ & $13.97 \mathrm{~b}$ & $2.35 \mathrm{a}$ & $1.83 \mathrm{a}$ & $17.73 \mathrm{a}$ & $15.81 \mathrm{a}$ & 5.61a & $8.40 \mathrm{a}$ & $3.30 \mathrm{a}$ & $2.68 b$ \\
\hline & $\mathrm{HN}$ & $36.32 \mathrm{a}$ & $17.73 \mathrm{a}$ & $2.23 b$ & $1.82 \mathrm{a}$ & $15.49 \mathrm{c}$ & $13.74 \mathrm{c}$ & $5.62 \mathrm{a}$ & $8.44 \mathrm{a}$ & $3.40 \mathrm{a}$ & $2.95 \mathrm{a}$ \\
\hline & Mean & 30.92 & 14.12 & 2.32 & 1.84 & 16.39 & 14.72 & 5.36 & 8.18 & 3.12 & 2.61 \\
\hline \multirow[t]{4}{*}{ Sheath } & $\mathrm{LN}$ & $9.68 \mathrm{c}$ & $3.72 \mathrm{c}$ & $2.06 \mathrm{c}$ & $1.14 \mathrm{~b}$ & $13.54 \mathrm{c}$ & $12.34 \mathrm{~b}$ & $0.87 \mathrm{~b}$ & $1.60 \mathrm{c}$ & $1.63 \mathrm{c}$ & $1.48 \mathrm{~b}$ \\
\hline & $\mathrm{MN}$ & $11.78 \mathrm{~b}$ & $5.23 b$ & $2.63 \mathrm{a}$ & $1.19 \mathrm{ab}$ & $15.51 \mathrm{a}$ & $13.60 \mathrm{a}$ & $1.03 \mathrm{a}$ & $1.86 \mathrm{a}$ & $2.09 \mathrm{a}$ & $1.45 \mathrm{c}$ \\
\hline & HN & $13.96 \mathrm{a}$ & $6.92 \mathrm{a}$ & $2.10 \mathrm{~b}$ & $1.20 \mathrm{a}$ & $14.37 \mathrm{~b}$ & $13.84 \mathrm{a}$ & $1.04 \mathrm{a}$ & $1.82 \mathrm{~b}$ & $1.87 \mathrm{~b}$ & $1.56 \mathrm{a}$ \\
\hline & Mean & 11.81 & 5.29 & 2.26 & 1.18 & 14.47 & 13.26 & 0.98 & 1.76 & 1.87 & 1.50 \\
\hline \multirow[t]{4}{*}{ Bracts } & $\mathrm{LN}$ & $9.77 b$ & $4.82 \mathrm{~b}$ & $0.74 \mathrm{a}$ & $0.53 a$ & $6.03 b$ & $5.52 b$ & $0.46 \mathrm{c}$ & $0.93 \mathrm{c}$ & $1.42 \mathrm{a}$ & $0.60 \mathrm{c}$ \\
\hline & $\mathrm{MN}$ & $13.23 \mathrm{a}$ & $8.76 \mathrm{a}$ & $0.70 \mathrm{~b}$ & $0.51 \mathrm{~b}$ & $6.01 \mathrm{~b}$ & $5.33 c$ & $0.50 \mathrm{~b}$ & $1.05 \mathrm{~b}$ & $1.38 \mathrm{a}$ & $0.66 b$ \\
\hline & $\mathrm{HN}$ & $12.69 \mathrm{a}$ & $8.59 a$ & $0.75 \mathrm{a}$ & $0.52 \mathrm{a}$ & $6.21 \mathrm{a}$ & $5.75 \mathrm{a}$ & $0.57 \mathrm{a}$ & $1.09 \mathrm{a}$ & $1.38 \mathrm{a}$ & $0.69 \mathrm{a}$ \\
\hline & Mean & 11.90 & 7.39 & 0.73 & 0.52 & 6.08 & 5.54 & 0.51 & 1.02 & 1.39 & 0.65 \\
\hline \multirow[t]{4}{*}{ Grain } & LN & $14.09 \mathrm{c}$ & $13.26 \mathrm{c}$ & $3.77 b$ & $3.20 \mathrm{~b}$ & $4.45 \mathrm{c}$ & $3.58 \mathrm{~b}$ & $1.08 \mathrm{~b}$ & $0.29 \mathrm{c}$ & $2.45 b$ & $1.06 \mathrm{~b}$ \\
\hline & $\mathrm{MN}$ & $16.16 \mathrm{~b}$ & $14.72 \mathrm{~b}$ & $3.87 \mathrm{~b}$ & $3.34 \mathrm{a}$ & $5.22 b$ & $4.04 \mathrm{a}$ & $1.19 \mathrm{a}$ & $0.36 \mathrm{a}$ & $2.56 \mathrm{a}$ & $1.20 \mathrm{a}$ \\
\hline & $\mathrm{HN}$ & $17.43 \mathrm{a}$ & $16.93 \mathrm{a}$ & $4.25 \mathrm{a}$ & $3.12 \mathrm{~b}$ & $5.62 \mathrm{a}$ & $3.68 b$ & $1.18 \mathrm{a}$ & $0.32 \mathrm{~b}$ & $2.61 \mathrm{a}$ & $1.18 \mathrm{a}$ \\
\hline & Mean & 15.89 & 14.97 & 3.97 & 3.22 & 5.10 & 3.76 & 1.15 & 0.32 & 2.54 & 1.14 \\
\hline
\end{tabular}

Low rate of $\mathrm{N}$ topdressing (LN, $0.8 \mathrm{~g} \mathrm{~N} /$ pot); medium rate of $\mathrm{N}(\mathrm{MN}, 1.6 \mathrm{~g} \mathrm{~N} /$ pot); high rate of N (HN, $2.4 \mathrm{~g} \mathrm{~N} /$ pot)

$D A A$ day after anthesis

*Data within a column followed by different lowercase letters are significantly different at $P<0.05$

Table 3 Concentrations of micronutrients in leaf, sheath, bracts, and grain under three $\mathrm{N}$ treatments

\begin{tabular}{|c|c|c|c|c|c|c|c|c|c|}
\hline \multirow[t]{2}{*}{ Organ } & \multirow{2}{*}{$\begin{array}{l}\text { Nitrogen } \\
\text { treatment }\end{array}$} & \multicolumn{2}{|c|}{$\mathrm{Fe}\left(\mu \mathrm{g} \mathrm{g}^{-1}\right)$} & \multicolumn{2}{|c|}{$\mathrm{Zn}\left(\mu \mathrm{g} \mathrm{g}^{-1}\right)$} & \multicolumn{2}{|c|}{$\operatorname{Mn}\left(\mu g^{-1}\right)$} & \multicolumn{2}{|c|}{$\mathrm{Cu}\left(\mu \mathrm{g} \mathrm{g}^{-1}\right)$} \\
\hline & & 7 DAA & 35 DAA & 7 DAA & $35 \mathrm{DAA}$ & 7 DAA & 35 DAA & 7 DAA & $35 \mathrm{DAA}$ \\
\hline \multirow[t]{4}{*}{ Leaf } & $\mathrm{LN}$ & $95.34 b^{*}$ & $144.36 \mathrm{c}$ & $28.13 b$ & $23.00 \mathrm{a}$ & $481.02 \mathrm{c}$ & $1002.52 \mathrm{c}$ & $3.82 b$ & $2.46 \mathrm{c}$ \\
\hline & $\mathrm{MN}$ & $108.18 \mathrm{a}$ & $163.23 \mathrm{a}$ & $29.78 \mathrm{a}$ & $23.88 \mathrm{a}$ & $795.78 b$ & $1358.10 \mathrm{~b}$ & $4.58 \mathrm{a}$ & $3.30 \mathrm{~b}$ \\
\hline & $\mathrm{HN}$ & $109.05 \mathrm{a}$ & $153.48 b$ & 29.26ab & $24.08 \mathrm{a}$ & $898.13 \mathrm{a}$ & $1462.68 \mathrm{a}$ & $4.76 \mathrm{a}$ & $3.65 \mathrm{a}$ \\
\hline & Mean & 104.19 & 153.69 & 29.06 & 23.65 & 724.98 & 1274.43 & 4.39 & 3.14 \\
\hline \multirow[t]{4}{*}{ Sheath } & $\mathrm{LN}$ & $77.29 \mathrm{c}$ & $149.23 \mathrm{c}$ & $51.58 \mathrm{c}$ & $48.69 \mathrm{~b}$ & $269.46 c$ & $250.03 \mathrm{c}$ & $2.01 \mathrm{c}$ & $1.63 c$ \\
\hline & $\mathrm{MN}$ & $88.53 b$ & $184.06 \mathrm{~b}$ & $63.07 \mathrm{a}$ & $56.24 \mathrm{a}$ & $449.48 b$ & $378.64 b$ & $2.41 \mathrm{a}$ & $1.98 \mathrm{~b}$ \\
\hline & $\mathrm{HN}$ & $105.36 \mathrm{a}$ & $214.33 \mathrm{a}$ & $59.38 \mathrm{~b}$ & $56.99 \mathrm{a}$ & $492.15 a$ & $434.17 \mathrm{a}$ & $2.36 \mathrm{~b}$ & $2.22 \mathrm{a}$ \\
\hline & Mean & 90.39 & 182.54 & 58.01 & 53.97 & 403.70 & 354.28 & 2.26 & 1.94 \\
\hline \multirow[t]{4}{*}{ Bracts } & LN & $22.78 \mathrm{c}$ & $55.48 \mathrm{~b}$ & $39.42 \mathrm{c}$ & $28.22 \mathrm{c}$ & $175.49 \mathrm{c}$ & $138.06 \mathrm{c}$ & $3.38 \mathrm{~b}$ & $2.70 \mathrm{~b}$ \\
\hline & $\mathrm{MN}$ & $23.54 b$ & $60.31 \mathrm{a}$ & $47.55 \mathrm{a}$ & $36.89 a$ & $214.64 b$ & $172.89 b$ & $3.92 \mathrm{a}$ & $3.08 \mathrm{a}$ \\
\hline & $\mathrm{HN}$ & $24.47 \mathrm{a}$ & $60.66 a$ & $42.47 \mathrm{~b}$ & $33.91 \mathrm{~b}$ & $258.95 \mathrm{a}$ & $197.56 a$ & $3.15 \mathrm{c}$ & $2.50 \mathrm{c}$ \\
\hline & Mean & 23.60 & 58.82 & 43.14 & 33.00 & 216.36 & 169.50 & 3.48 & 2.76 \\
\hline \multirow[t]{4}{*}{ Grain } & $\mathrm{LN}$ & $33.94 \mathrm{a}$ & $15.85 \mathrm{a}$ & $26.21 \mathrm{~b}$ & $18.63 \mathrm{a}$ & $50.24 \mathrm{c}$ & $18.70 \mathrm{c}$ & $4.53 b$ & $4.95 \mathrm{a}$ \\
\hline & MN & $31.49 \mathrm{a}$ & $15.33 \mathrm{a}$ & $29.60 \mathrm{a}$ & $18.18 \mathrm{a}$ & $68.39 \mathrm{~b}$ & $28.22 \mathrm{~b}$ & $4.59 \mathrm{ab}$ & $4.44 c$ \\
\hline & $\mathrm{HN}$ & $30.35 a$ & $14.44 b$ & $31.80 \mathrm{a}$ & $18.09 \mathrm{a}$ & $71.27 \mathrm{a}$ & $31.66 \mathrm{a}$ & $4.81 \mathrm{a}$ & $4.63 b$ \\
\hline & Mean & 30.67 & 15.21 & 29.20 & 18.30 & 63.30 & 26.20 & 4.65 & 4.67 \\
\hline
\end{tabular}

Low rate of $\mathrm{N}$ topdressing (LN, $0.8 \mathrm{~g} \mathrm{~N} /$ pot); medium rate of $\mathrm{N}$ (MN, $1.6 \mathrm{~g} \mathrm{~N} /$ pot); high rate of $\mathrm{N}$ (HN, $2.4 \mathrm{~g} \mathrm{~N} /$ pot)

$D A A$ day after anthesis

*Data within a column followed by different lowercase letters are significantly different at $P<0.05$ 


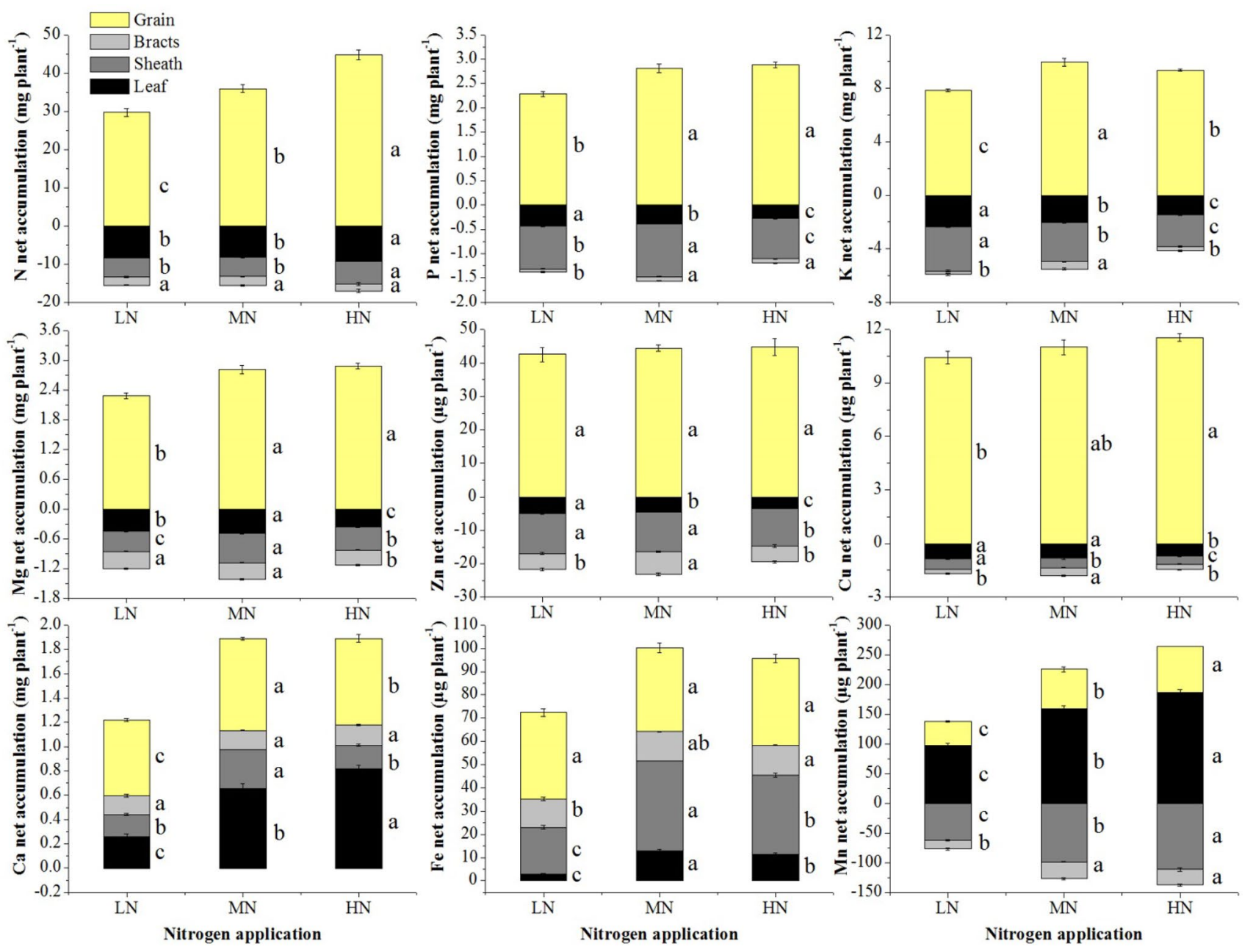

Fig. 1 Net accumulation of macronutrients and micronutrients in leaf, sheath, bracts and grain during grain filling (between 7 and 35 days after anthesis) and its variation with $\mathrm{N}$ treatments. Data within a col-

\section{Net accumulation of mineral nutrients in leaf, sheath, and bracts}

The net accumulation of each mineral nutrient was calculated by subtraction of its content (mg/plant or $\mu \mathrm{g} /$ plant) at 35 DAA by its content at 7 DAA. As shown in Fig. 1, the value of net accumulation of $\mathrm{N}, \mathrm{P}, \mathrm{K}, \mathrm{Mg}, \mathrm{Zn}$, and $\mathrm{Cu}$ in leaf, sheath, and bracts were all below zero, indicating that these mineral nutrients were remobilized from these vegetative organs during grain filling. In contrast, net accumulation of $\mathrm{Ca}$ and $\mathrm{Fe}$ in leaf, sheath, and bracts, and of $\mathrm{Mn}$ in leaf, were all positive numbers, implying that these vegetative organs were also sinks of $\mathrm{Ca}, \mathrm{Fe}$, and $\mathrm{Mn}$, similar to the developing grains.

Nitrogen topdressing positively affected the net accumulations of $\mathrm{N}, \mathrm{Ca}, \mathrm{Fe}$, and $\mathrm{Mn}$ in leaves and sheaths, while that of $\mathrm{P}, \mathrm{K}, \mathrm{Zn}$, and $\mathrm{Cu}$ was depressed (Fig. 1). In addition, $\mathrm{N}$ fertilization had a positive effect on the net accumulation umn followed by different lowercase letters are significantly different at $P<0.05$. Low rate of $\mathrm{N}$ topdressing ( $\mathrm{LN}, 0.8 \mathrm{~g} \mathrm{~N} / \mathrm{pot}$ ); medium rate of $\mathrm{N}(\mathrm{MN}, 1.6 \mathrm{~g} \mathrm{~N} / \mathrm{pot})$; high rate of $\mathrm{N}(\mathrm{HN}, 2.4 \mathrm{~g} \mathrm{~N} /$ pot $)$

of $\mathrm{P}$ in rice bracts but a negative effect on net accumulation in leaves and sheaths.

\section{Contribution rate of leaf, sheath, and bracts to grain mineral nutrient accumulation}

As shown above, leaf, sheath, and bracts are source organs, supplying $\mathrm{N}, \mathrm{P}, \mathrm{K}, \mathrm{Mg}, \mathrm{Zn}$, and $\mathrm{Cu}$ for grain filling. Therefore, we calculated the apparent contribution rate of leaf, sheath, and bracts to grains in terms of the six mineral nutrients. The contribution rate of each mineral nutrient was calculated using the following formula: (apparent translocation of mineral nutrient of a vegetative organ from 7 DAA to 35 DAA)/(mineral nutrient accumulation at $35 \mathrm{DAA}$ - accumulation at 7 DAA in grain). Note that apparent translocation of each mineral nutrient from a vegetative organ was the opposite of net accumulation (Tables 2, 3). 
Table 4 Contribution rate of leaf, sheath, and bracts of six mineral elements to grains under three $\mathrm{N}$ treatments $(\%)$

\begin{tabular}{|c|c|c|c|c|c|c|c|}
\hline \multirow[t]{2}{*}{ Organ } & \multirow{2}{*}{$\begin{array}{l}\text { Nitrogen } \\
\text { treatment }\end{array}$} & \multicolumn{6}{|c|}{ Mineral elements } \\
\hline & & $\mathrm{N}$ & $\mathrm{P}$ & $\mathrm{K}$ & $\mathrm{Mg}$ & $\mathrm{Zn}$ & $\mathrm{Cu}$ \\
\hline \multirow[t]{4}{*}{ Leaf } & $\mathrm{LN}$ & $27.55 \mathrm{a}^{*}$ & $6.02 \mathrm{a}$ & $30.01 \mathrm{a}$ & $19.83 a$ & $11.86 \mathrm{a}$ & $8.29 \mathrm{a}$ \\
\hline & $\mathrm{MN}$ & $22.55 b$ & $4.64 b$ & $20.22 b$ & $17.39 \mathrm{~b}$ & $9.97 b$ & $7.43 b$ \\
\hline & $\mathrm{HN}$ & $20.44 c$ & $3.44 \mathrm{c}$ & $15.55 \mathrm{c}$ & $12.53 \mathrm{c}$ & $7.54 \mathrm{c}$ & $5.87 \mathrm{c}$ \\
\hline & Mean & 23.51 & 4.70 & 21.93 & 16.58 & 9.79 & 7.19 \\
\hline \multirow[t]{4}{*}{ Sheath } & $\mathrm{LN}$ & $17.07 \mathrm{a}$ & $12.22 \mathrm{~b}$ & $42.26 \mathrm{a}$ & $17.70 \mathrm{~b}$ & $27.90 \mathrm{a}$ & $5.58 \mathrm{a}$ \\
\hline & $\mathrm{MN}$ & $13.89 b$ & $13.18 \mathrm{a}$ & $29.77 b$ & $21.07 \mathrm{a}$ & $26.92 \mathrm{a}$ & $4.95 \mathrm{~b}$ \\
\hline & $\mathrm{HN}$ & $13.12 b$ & $10.18 \mathrm{c}$ & $25.41 \mathrm{c}$ & $16.06 \mathrm{c}$ & $25.20 \mathrm{a}$ & $4.17 \mathrm{c}$ \\
\hline & Mean & 14.69 & 11.86 & 32.48 & 18.27 & 26.67 & 4.90 \\
\hline \multirow[t]{4}{*}{ Bracts } & $\mathrm{LN}$ & $7.19 \mathrm{a}$ & $0.83 b$ & $3.02 \mathrm{~b}$ & $15.07 \mathrm{a}$ & $11.14 \mathrm{~b}$ & $2.37 \mathrm{~b}$ \\
\hline & $\mathrm{MN}$ & $6.53 \mathrm{a}$ & $1.09 \mathrm{a}$ & $5.41 \mathrm{a}$ & $11.94 \mathrm{~b}$ & $15.13 \mathrm{a}$ & $4.13 \mathrm{a}$ \\
\hline & HN & $4.16 \mathrm{~b}$ & $1.05 \mathrm{a}$ & $3.27 \mathrm{~b}$ & $10.66 \mathrm{~b}$ & $10.74 b$ & $2.66 \mathrm{~b}$ \\
\hline & Mean & 5.96 & 0.99 & 3.90 & 12.56 & 12.34 & 3.05 \\
\hline
\end{tabular}

Low rate of $\mathrm{N}$ topdressing (LN, $0.8 \mathrm{~g} \mathrm{~N} /$ pot); medium rate of $\mathrm{N}(\mathrm{MN}, 1.6 \mathrm{~g} \mathrm{~N} /$ pot); high rate of $\mathrm{N}(\mathrm{HN}$, $2.4 \mathrm{~g} \mathrm{~N} / \mathrm{pot}$ )

*Data within a column followed by different lowercase letters are significantly different at $P<0.05$
As shown in Table 4, averaged across $\mathrm{N}$ treatments, the contribution rates of leaf to grains of $\mathrm{N}, \mathrm{P}, \mathrm{K}, \mathrm{Mg}, \mathrm{Zn}$, and $\mathrm{Cu}$ were $23.51,4.70,21.93,16.58,9.79$, and $7.19 \%$, respectively. For sheath to grains the contribution rates were $14.69,11.86,32.48,18.27,26.67$, and $4.90 \%$, respectively. Considerable contribution rate of bracts for $\mathrm{N}, \mathrm{Mg}$, and $\mathrm{Zn}$ was detected, with mean values of 5.96, 12.56, and $12.34 \%$, respectively. Also, the calculation showed minor contribution of bracts with respect to $\mathrm{P}, \mathrm{K}$, and $\mathrm{Cu}$, with mean values of $0.99,3.90$, and $3.05 \%$, respectively.

Nitrogen topdressing lowered the contribution rate of all the mineral nutrients for leaf and sheath. For instance, the contribution rate of leaf $\mathrm{N}$ to grains was $27.55 \%$ for $\mathrm{LN}$ but $20.44 \%$ for HN. Also, the contribution rate of $\mathrm{K}$ in sheath was $42.26 \%, 29.77 \%$, and $25.41 \%$ for $\mathrm{LN}, \mathrm{MN}$, and $\mathrm{HN}$, respectively. In addition, $\mathrm{N}$ application tended to decrease the contribution rate of bracts except for $\mathrm{P}$.

\section{Discussion}

\section{Remobilization of mineral nutrients from bracts to grain}

Nitrogen absorption by cereals occurs mainly before anthesis, with a value of about $85 \%$ for rice ( $\mathrm{Li}$ et al. 2014). Therefore, the major part of grain $\mathrm{N}$ is transferred from the vegetative organs. Typically, only $10-30 \%$ of $\mathrm{N}$ in mature cereal is retained in the senesced leaves, with the major part being remobilized to sink organs like grains (Gregersen 2011). In rice, the remobilization (redistribution) rate of leaf $\mathrm{N}$ and its contribution rate to grains were 76.88 and $21.74 \%$, respectively (Zhao et al. 2015). Similar to leaf, bracts of rice spikelets are also important source organs, contributing heavily to grain $\mathrm{N}$ accumulation. A previous study showed a considerable contribution rate of protein- $\mathrm{N}$ in bracts to grain filling, with values as high as 10.19 and $9.77 \%$ for superior and inferior grains, respectively (Zhang et al. 2017). In the present study, averaged contribution rates of total $\mathrm{N}$ in leaf, sheath, and bracts to grains were $23.51,14.69$, and $5.96 \%$, respectively. The values are relatively lower than that of Zhang et al. (2017), probably because the current study assayed the total $\mathrm{N}$ content of the samples from 7 DAA to maturity, while the former measured the samples in protein- $\mathrm{N}$ content from 0 DAA to maturity, a highly removable fraction of leaf total N. Nevertheless, these results jointly suggest an important role of rice bracts in providing $\mathrm{N}$ for grain filling.

Magnesium is a crucial component of chlorophyll required for plant photosynthesis. In soybean and wheat, seed/grain Mg appears to be mobilized from leaves, partially because of its high phloem mobility (Maillard et al. 2015). Zinc is also essential for rice plants, and more than half of grain $\mathrm{Zn}$ is remobilized from that accumulated and stored in leaf, sheath, and stem before anthesis (Wu et al. 2010; Yilmaz et al. 2016). In this study, a considerable contribution rate of $\mathrm{Mg}$ and $\mathrm{Zn}$ nutrients of the bracts was detected, with values as high as 12.56 and $12.34 \%$, respectively, in comparison with that of the leaf (16.58 and 9.79\%), and sheath (18.27 and 26.67\%). This result suggested that the bracts of rice are an important transient organ for the loading of $\mathrm{Mg}$ and $\mathrm{Zn}$ into developing grains.

In rice, about $25 \%$ of $\mathrm{P}$ is absorbed and accumulated during grain filling, and the remobilization from vegetative organs accounts for about $20 \%$ of the grain P (Li et al. 2014; Julia et al. 2016). Potassium uptake by cereals occurs mainly 
before anthesis, at about $90 \%$ for rice, and vegetative organs including leaves, stem, and sheaths contribute nearly $60 \%$ of grain $\mathrm{K}$ at maturity ( $\mathrm{Li}$ et al. 2014). The extent of $\mathrm{Cu}$ remobilization within plants was species dependent, and showed the lowest remobilization in rice compared with other crops (Barunawati et al. 2013; Maillard et al. 2015). In the current study, a minor contribution of bracts to grain $\mathrm{P}, \mathrm{K}$, and $\mathrm{Cu}$ was detected, with contribution rates of $0.99,3.90$, and $3.05 \%$, respectively. Similarly, other vegetative organs like leaf and sheath contributed a small part of $\mathrm{P}$ and $\mathrm{Cu}$. These findings indicate that the major part of grain $\mathrm{P}$ and $\mathrm{Cu}$ should originate from other sources like stem or from root uptake after anthesis, as shown in Fig. 2.

Calcium is less mobile in the phloem, and its continuous accumulation in leaf even after anthesis has been well established (Himelblau and Amasino 2001; Maillard et al. 2015). Iron is inefficient for remobilization between vegetative organs and grains, and a study on rice showed that only $4 \%$ of total shoot $\mathrm{Fe}$ was translocated to grain (Marr et al.
1995). Due to poor phloem mobilization, Mn appears to be an immobile nutrient in leaves of wheat (Pearson and Rengel 1994) and barley (Maillard et al. 2015). In the current study, the net accumulation of $\mathrm{Ca}, \mathrm{Fe}$, and $\mathrm{Mn}$ increased during grain filling, not only in the grains but also for the vegetative organs, in particular the leaves, indicating that leaves are also a sink of these mineral nutrients. Interestingly, concentrations of $\mathrm{Ca}, \mathrm{Fe}$, and $\mathrm{Mn}$ in grains decreased dramatically during grain filling, with the late stage (35 DAA) showing a two to threefold decrease in comparison with the early stage (7 DAA). Since the leaf, sheath, and bracts are also sink organs, other sources including remobilization from stem and uptake by root should be crucial for the accumulation of $\mathrm{Ca}, \mathrm{Fe}$, and $\mathrm{Mn}$ in rice grains.

In summary, the patterns of the remobilization of $\mathrm{N}, \mathrm{P}, \mathrm{K}$, $\mathrm{Mg}, \mathrm{Zn}$, and $\mathrm{Cu}$ during rice grain filling were summarized according to the results of the current study (Fig. 2). Of note is that the contributions of leaf, sheath, and bracts only account for part of the amount of these mineral nutrients

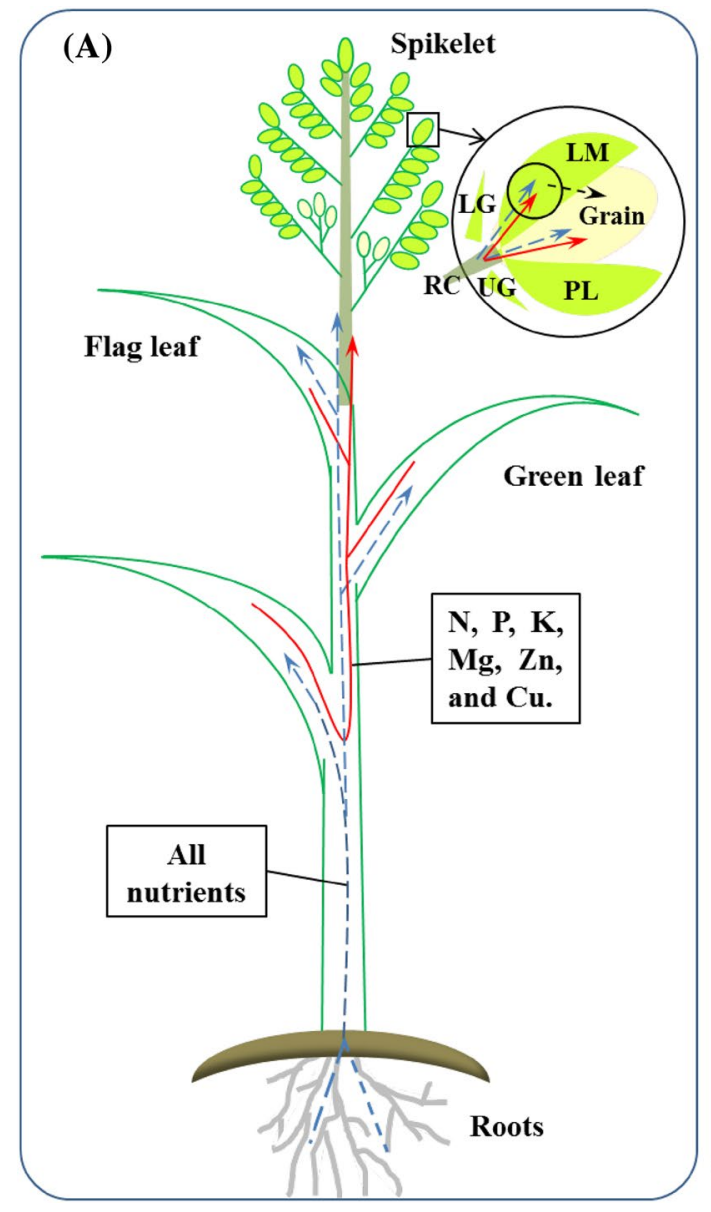

Fig. 2 Schematic presentation of allocation of mineral nutrients to grains (a) and the contribution of vegetative organs of leaf, sheath, and bracts to grains (b). Dashed blue line indicates root uptake, solid red line indicates remobilization of minerals from leaf and sheath,

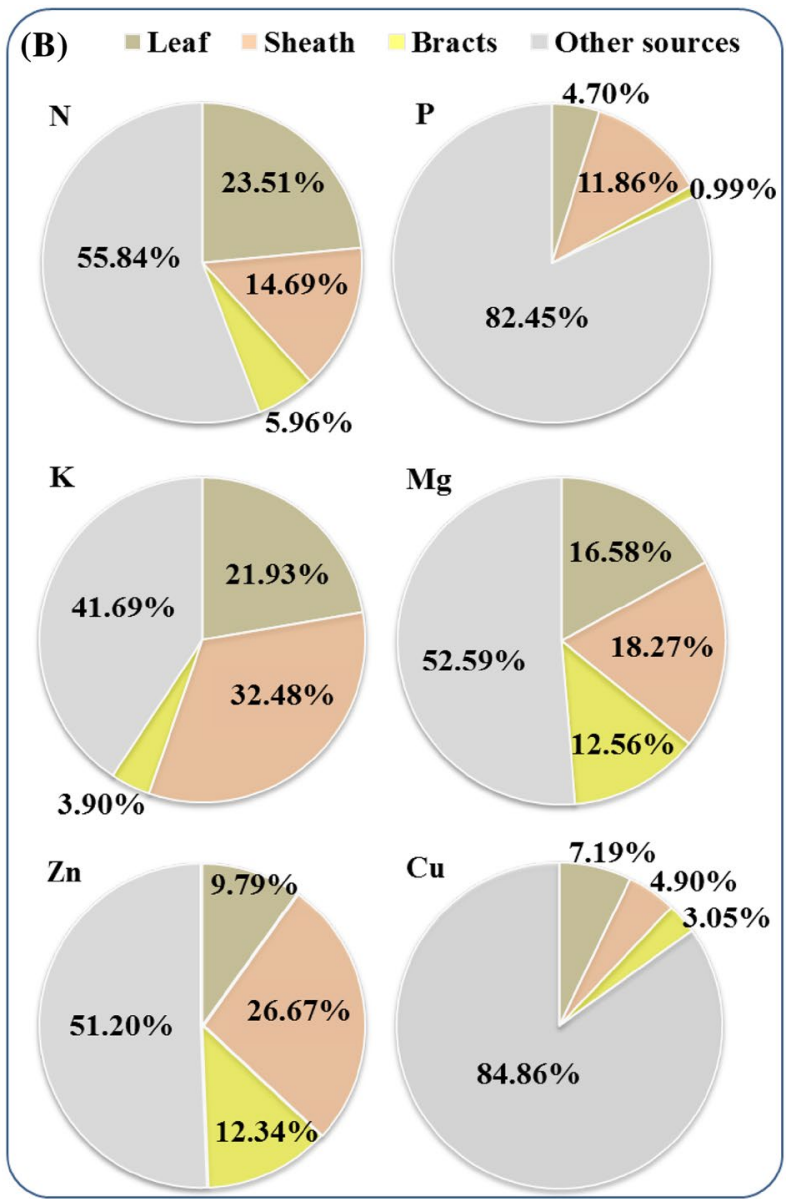

and dashed black line indicates remobilization of minerals from bracts. Data are averages of $\mathrm{N}$ treatments. Other sources include remobilization of minerals from stem and root uptake. $L G$ lower glume, $L M$ lemma, $P L$ palea, $R C$ rachilla, $U G$ upper glume 
in grains, and other sources including remobilization from stem and uptake by root are also essential for grain mineral nutrient accumulation.

\section{Effect of $\mathbf{N}$ fertilization on grain mineral nutrients}

Nitrogen fertilization, especially topdressing at the panicle initiation stage, is widely adopted as a high-yielding technology by rice growers (Ogawa et al. 2016). While rice plant tends to maintain the homeostasis of mineral nutrition in grains within a specific range, application of $\mathrm{N}$ fertilizers can alter the balance. For rice grain, the medium level of $\mathrm{N}$ application promoted the accumulation of $\mathrm{Cu}, \mathrm{Fe}, \mathrm{Mn}$, and $\mathrm{Zn}$ in brown rice (Hao et al. 2007). Lin et al. (2014) found that addition of $\mathrm{N}$ fertilizers tended to lower $\mathrm{Zn}$ accumulation in brown rice, while the trends for $\mathrm{Cu}, \mathrm{Fe}$, and $\mathrm{Mn}$ followed no specific pattern. Jaksomsak et al. (2017) reported that increasing $\mathrm{N}$ rate increased grain $\mathrm{Zn}$ concentration and yield in the high-yield/low grain Zn cultivars, but depressed grain $\mathrm{Zn}$ concentration and increased grain yield in the lowyield/high grain $\mathrm{Zn}$ cultivars. In this study, grains produced at the MN topdressing level had higher $\mathrm{Fe}$ and similar $\mathrm{Zn}$ concentration in comparison with those at the $\mathrm{HN}$ level. The $\mathrm{Zn}$ concentration of the japonica cultivar Huaidao 5 used in the current study was similar to that designated as low grain $\mathrm{Zn}$ cultivars by Jaksomsak et al. (2017), but exhibited a different pattern, suggesting genotypic differences in the response of grain $\mathrm{Zn}$ to $\mathrm{N}$ fertilization. Importantly, there was no statistically significant difference in grain yield between $\mathrm{MN}$ and $\mathrm{HN}$, indicating the possibility of appropriate $\mathrm{N}$ management for maintaining $\mathrm{Fe}$ and $\mathrm{Zn}$ level under high yielding conditions.

\section{Conclusions}

This study quantified the contribution of rice bracts to grain in terms of minerals, and examined the effect of nitrogen topdressing. The role of bracts was clarified, providing a substantial portion of $\mathrm{N}, \mathrm{Mg}$, and $\mathrm{Zn}$ for grains, while being a sink organ of $\mathrm{Ca}$ and $\mathrm{Fe}$, as their net increase during grain filling. In addition, $\mathrm{N}$ topdressing depressed the remobilization of $\mathrm{N}, \mathrm{Mg}, \mathrm{Zn}, \mathrm{K}$, and $\mathrm{Cu}$ from bracts to grains but increased that of $\mathrm{P}$. Collectively, these findings suggests the necessity of studying on bracts when elucidating the physiological mechanism underlying grain filling, a crucial process for the formation of both rice yield and quality.

Acknowledgements This work was supported in part by Grants from the Special Fund for Agro-scientific Research in the Public Interest (201503130), the National Natural Science Foundation of China (31771719), and National High Technology Research and Development Program of China (2014AA10A605).
Open Access This article is distributed under the terms of the Creative Commons Attribution 4.0 International License (http://creativeco mmons.org/licenses/by/4.0/), which permits unrestricted use, distribution, and reproduction in any medium, provided you give appropriate credit to the original author(s) and the source, provide a link to the Creative Commons license, and indicate if changes were made.

\section{References}

Bao SD (2000) Soil agro-chemistrical analysis, 2nd edn. China Agriculture Press, Beijing (in Chinese)

Barunawati N, Giehl RFH, Bauer B, Wirén NW (2013) The influence of inorganic nitrogen fertilizer forms on micronutrient retranslocation and accumulation in grains of winter wheat. Front Plant Sci 4:1-11

Bi JG, Liu ZH, Lin ZM, Alim MA, Rehmani MIA, Li GH, Wang QS, Wang SH, Ding YF (2013) Phosphorus accumulation in grains of japonica rice as affected by nitrogen fertilizer. Plant Soil 369:231-240

Cakmak I (2008) Enrichment of cereal grains with zinc: agronomic or genetic biofortification? Plant Soil 302:1-17

Chen TT, Xu GW, Wang ZQ, Zhang H, Yang JC, Zhang JH (2016) Expression of proteins in superior and inferior spikelets of rice during grain filling under different irrigation regimes. Proteomics 16:102-121

Erenoglu EB, Kutman UB, Ceylan Y, Yildiz B, Cakmak I (2011) Improved nitrogen nutrition enhances root uptake, root-to-shoot translocation and remobilization of zinc $\left({ }^{65} \mathrm{Zn}\right)$ in wheat. New Phytol 189:438-448

Gregersen PL (2011) Senescence and nutrient remobilization in crop plants. In: Hawkesford MJ, Barraclough P (eds) The molecular and physiological basis of nutrient use efficiency in crops. Wiley, Chichester, pp 83-102

Hao HL, Wei YZ, Yang XE, Feng Y, Wu CY (2007) Effects of different nitrogen fertilizer levels on $\mathrm{Fe}, \mathrm{Mn}, \mathrm{Cu}$ and $\mathrm{Zn}$ concentrations in shoot and grain quality in rice (Oryza sativa). Rice Sci 14:289-294

Himelblau E, Amasino RM (2001) Nutrients mobilized from leaves of Arabidopsis thaliana, during leaf senescence. J Plant Physiol 158:1317-1323

Huang Y, Tong C, Xu FF, Chen YL, Zhang CY, Bao JS (2016) Variation in mineral elements in grains of 20 brown rice accessions in two environments. Food Chem 192:873-878

Jaksomsak P, Rerkasem B, Prom-U-Thai C (2017) Responses of grain zinc and nitrogen concentration to nitrogen fertilizer application in rice varieties with high-yielding low-grain zinc and low-yielding high grain zinc concentration. Plant Soil 411:101-109

Julia C, Wissuwa M, Kretzschmar T, Jeong K, Rose T (2016) Phosphorus uptake, partitioning and redistribution during grain filling in rice. Ann Bot 118:1151-1162

Kutman UB, Yildiz B, Cakmak I (2011) Effect of nitrogen on uptake, remobilization and partitioning of zinc and iron throughout the development of durum wheat. Plant Soil 342:149-164

Li M, Zhang HC, Yang X, Ge MJ, Ma Q, Wei HY, Dai QG, Huo ZY, Xu K, Luo DQ (2014) Accumulation and utilization of nitrogen, phosphorus and potassium of irrigated rice cultivars with high productivities and high $\mathrm{N}$ use efficiencies. Field Crops Res 161:55-63

Lin ZM, Ning HF, Bi JG, Qiao JF, Liu ZH, Li GH, Wang QH, Wang SH, Ding YF (2014) Effects of nitrogen fertilization and genotype on rice grain macronutrients and micronutrients. Rice Sci $21: 233-242$ 
Maillard A, Diquélou S, Billard V, Laîné P, Garnica M, Prudent M, Garcia-Mina JM, Yvin JC, Ourry A (2015) Leaf mineral nutrient remobilization during leaf senescence and modulation by nutrient deficiency. Front Plant Sci 6:1-15

Marr KM, Batten GD, Blakeney AB (1995) Relationships between minerals in Australian brown rice. J Sci Food Agric 68:285-291

Murgia I, Arosio P, Tarantino D, Soave C (2012) Biofortification for combating 'hidden hunger' for iron. Trends Plant Sci 17:47-55

Ogawa T, Oikawa S, Hirose T (2016) Nitrogen-utilization efficiency in rice: an analysis at leaf, shoot, and whole-plant level. Plant Soil 404:321-344

Pearson JN, Rengel Z (1994) Distribution and remobilization of Zn and Mn during grain development in wheat. J Exp Bot 45:1829-1835

Promchan J, Günther D, Siripinyanond A, Shiowatana J (2016) Elemental imaging and classifying rice grains by using laser ablation inductively coupled plasma mass spectrometry and linear discriminant analysis. J Cereal Sci 71:198-203

Simpson RJ, Lambers H, Dalling MJ (1983) Nitrogen redistribution during grain growth in wheat (Triticum aestivum L.). Plant Physiol $71: 7-14$

Sperotto RA, Ricachenevsky FK, Duarte GL, Boff T, Lopes KL, Sperb ER, Grusak MA, Fett JP (2009) Identification of up-regulated genes in flag leaves during rice grain filling and characterization of OsNAC5, a new ABA-dependent transcription factor. Planta 230:985-1002

Waters BM, Uauy C, Dubcovsky J, Grusak MA (2009) Wheat (Triticum aestivum) NAM proteins regulate the translocation of iron, zinc, and nitrogen compounds from vegetative tissues to grain. J Exp Bot 60:4263-4274

Wu CY, Lu LL, Yang XE, Feng Y, Wei YY, Hao HL, Stoffella PJ, He ZL (2010) Uptake, translocation, and remobilization of zinc absorbed at different growth stages by rice genotypes of different Zn densities. J Agric Food Chem 58:6767-6773

Yilmaz O, Kazar GA, Cakmak I, Ozturk L (2016) Differences in grain zinc are not correlated with root uptake and grain translocation of zinc in wild emmer and durum wheat genotypes. Plant Soil 411:69-79

Zhang XC, Lei JC, Zheng DY, Liu ZH, Li GH, Wang SH, Ding YF (2017) Amino acid composition of leaf, grain and bracts of japonica rice (Oryza Sativa ssp. japonica) and its response to nitrogen fertilization. Plant Growth Regul 82:1-9

Zhao YL, Xi M, Zhang XC, Lin ZM, Ding CQ, Tang S, Liu ZH, Wang SH, Ding YF (2015) Nitrogen effect on amino acid composition in leaf and grain of japonica rice during grain filling stage. J Cereal Sci 64:29-33 